\title{
ANALISIS PENGARUH KUALITAS PRODUK, KUALITAS LAYANAN DAN HARGA TERHADAP KEPUASAN KONSUMEN (Studi Kasus Pada Konsumen Industry/ Toko Bakery di Kota Bengkulu)
}

\author{
Herry Novrianda \\ Fakultas Ekonomi Universitas Dehasen Bengkulu \\ Email: herry993@gmail.com
}

\begin{abstract}
The objective of this research is to analyze the effect of product quality, service quality and price toward customer satisfaction on industry/ bakery shop in the Bengkulu city. This study is a descriptive research which aims to clarify the relationship or influence that exist between the variables studied. The type of data used a primary data that is collected from questionnaires. Respondents of this study is the customer industry/bakery shop in Bengkulu city as many 2400 people were taken with the judgemental (purposive sampling) technique. The methods of data analysis used are descriptive analysis by using the mean, frequency distribution table and multiple linear regression analysis. Based on the analysis, the result that the simultaneously product quality, service quality, and price is significantly impact on customer satisfaction industry/bakery shop in the Bengkulu city. The next in partial product quality and service quality is positively and significantly impact on customer satisfaction industry/bakery shop in the Bengkulu city, while the price is negative and significantly impact on customer satisfaction industry/ bakery shop in the Bengkulu city.
\end{abstract}

Keyword: service, quality, satisfaction, bakery.

\section{PENDAHULUAN}

Pada era globalisasi seperti sekarang ini, industry yang tetap ramai dan terus berkembang adalah industry bakery. Perkembangan industry ini tidak saja terlihat dari makin banyaknya perusahaan yang menggeluti bisnis ini, tapi juga dari hasil produksi dan pemasarannya, baik pasar lokal maupun internasional (www.jsm-synergy.com). Adanya perkembangan yang pesat dalam industri bakery tersebut menuntut para pelaku bisnis dalam industry ini untuk mampu memaksimalkan kinerja perusahaannya agar dapat bersaing di pasar. Konsumen dalam memilih produk bakery yang diinginkan adalah suatu keputusan dimana konsumen melakukan pertimbangan-pertimbangan 
yang disesuaikan dengan keadaan atau kondisi yang ada untuk memenuhi kepuasannya. Kepuasan konsumen dapat didefinisikan secara sederhana yaitu suatu keadaan dimana kebutuhan, keinginan, dan harapan pelanggan dapat terpenuhi melalui produk yang dikonsumsi (Fatona, 2010).

Dapkevicius \& Melnikas (2009) menyatakan bahwa kualitas merupakan faktor penting untuk kepuasan pelanggan yang mengarah ke keputusan kompleksitas pemasaran saat ini. Senthilkumar (2012) juga menyatakan bahwa kualitas produk berpengaruh pada kepuasan pelanggan. Kualitas produk merupakan faktor-faktor yang terdapat dalam suatu barang atau hasil yang menyebabkan barang atau hasil tersebut sesuai dengan tujuan untuk apa barang atau hasil itu dimaksudkan (Assauri, 2004). Produk dipandang berkualitas apabila memenuhi apa yang konsumen harapkan, sebaliknya produk dipersepsikan tidak berkualitas apabila tidak memenuhi harapan konsumen. Kualitas layanan juga merupakan faktor penting kepuasan pelanggan dalam industri manufaktur maupun di perusahaan jasa (Malik et al, 2012). Kualitas layanan merupakan tingkat keunggulan sebuah layanan untuk memenuhi keinginan pelanggan (Tjiptono, 2006). Layanan berkualitas tinggi akan memiliki dampak positif pada kepuasan pelanggan. Kualitas layanan dipandang baik apabila memenuhi apa yang pelanggan harapkan, sebaliknya kualitas layanan akan dipersepsikan buruk apabila tidak memenuhi harapan konsumen.

Kepuasan konsumen juga dipengaruhi oleh faktor harga. Kewajaran harga mempengaruhi kepuasan pelanggan dengan cara yang positif tetapi keadilan harga yang dirasakan dapat berpengaruh secara negatif oleh kerentanan pelanggan (Herrmann et al, 2007). Harga memiliki hubungan dengan kepuasan pelanggan, kenaikan harga telah terbukti memiliki dampak negatif pada kepuasan pelanggan (Malik et al, 2012). Ketika pelanggan percaya bahwa harga produk adalah wajar, perilaku pembelian cenderung diulang. Sebaliknya, jika pelanggan merasa bahwa produk atau layanan tertentu tidak layak harga, mereka tidak akan mengulangi perilaku pembelian (Ehsani \& Ehsani, 2014).

Berdasarkan pengamatan awal yang dilakukan pada beberapa industry/ toko bakery di Kota Bengkulu, kualitas produk, kualitas layanan dan harga yang ditawarkan oleh industri/ toko-toko bakery di Kota Bengkulu kepada konsumen pada dasarnya sudah cukup baik, namun belum secara menyeluruh memberikan kepuasan bagi konsumennya. Hal ini terlihat dari keistimewaan yang ditawarkan seperti: penampilan produk dan keunikan produk yang relatif masih sama antar semua toko-toko bakery serta masih adanya keluhan konsumen terhadap pelayanan yang diberikan oleh industri/ toko-toko bakery misalnya karyawan yang bersikap kurang ramah kepada seluruh konsumen atau terkadang hanya bersikap ramah kepada konsumenkonsumen tertentu saja. Selain itu masih ada toko-toko bakery yang menawarkan harga yang relatif masih mahal jika dibandingkan dengan harga produk yang ditawarkan oleh toko bakery lainnya yang ada di kota Bengkulu. 


\section{KAJIAN PUSTAKA}

\section{Kepuasan Konsumen}

Kepuasan konsumen dianggap sebagai penentu dasar perilaku konsumen jangka panjang (Yi, 1990), dan evaluasi secara keseluruhan layanan yang membentuk interaksi masa depan (Ehsani \& Ehsani, 2014). Dalam konteks hubungan pemasaran, kepuasan dikonseptualisasikan sebagai unsur konsep kualitas hubungan (Crosby et al., 1990). Kepuasan konsumen merupakan tingkat perasaan seseorang setelah membandingkan hasil yang dirasakan dengan harapannya (Kotler \& Amstrong, 2008). Stephen, et al (2007) menyebutkan bahwa outcome atau hasil yang diharapkan dari adanya kepuasan konsumen adalah peningkatan penggunaan, pembelian ulang, loyalitas dan word of mouth. Sedangkan menurut Kotler \& Amstrong (2008) ciri-ciri konsumen yang puas yaitu: 1). Loyal terhadap produk, konsumen yang puas terhadap produk yang dikonsumsinya akan mempunyai kecenderungan untuk membeli ulang dari produsen yang sama; 2). Adanya komunikasi dari mulut ke mulut yang bersifat positif, hal ini dapat berupa rekomendasi kepada calon konsumen yang lain dan mengatakan hal-hal yang baik mengenai produk dan perusahaan yang menyediakan produk; dan 3). Perusahaan menjadi pertimbangan utama ketika membeli produk lain, hal ini merupakan proses kognitif ketika adanya kepuasan.

\section{Kualitas Produk}

Hanya ada dua pilihan bagi perusahaan yaitu sukses dalam pengembangan produk sehingga menghasilkan produk yang unggul atau gagal dalam pencapaian tujuan bisnisnya karena produk yang tidak mampu bersaing dipasar (Cooper \& Kleinschmidt, 1987). Kualitas produk (product quality) merupakan pemahaman bahwa produk yang ditawarkan oleh penjual mempunyai nilai jual lebih yang tidak dimiliki produk pesaing. Oleh karena itu perusahaan berusaha memfokuskan pada kualitas produk dan membandingkannya dengan produk yang ditawarkan oleh perusahaan pesaing. Suatu produk dapat memuaskan konsumen bila dinilai dapat memenuhi atau melebihi keinginan dan harapannya (Spreng et al., 1996). Hal ini menggambarkan bahwa kualitas produk merupakan faktor yang sangat diperhatikan oleh pelanggan dalam membentuk kepuasan konsumen. Penelitian Senthilkumar (2012) menyatakan bahwa kualitas produk berpengaruh pada kepuasan pelanggan. Hal ini menunjukkan bahwa semakin baik persepsi konsumen terhadap kualitas produk maka kepuasan konsumen juga akan semakin tinggi dan jika persepsi konsumen terhadap kualitas produk buruk maka kepuasan konsumen juga akan semakin rendah. Assauri (2004) mengatakan bahwa kualitas produk merupakan faktor-faktor yang terdapat dalam suatu barang atau hasil yang menyebabkan barang atau hasil tersebut sesuai dengan tujuan untuk apa barang atau hasil itu 
dimaksudkan. Tjiptono (2006) menyatakan ada beberapa faktor yang digunakan untuk mengevaluasi tercapainya pemenuhan kebutuhan oleh suatu produk yaitu: kinerja (performance), ciri-ciri atau keistimewaan tambahan (feature), keandalan (reliability), kesesuaian dengan spesifikasi (conformance to specification), daya tahan (durability), servicebility, estetika serta kualitas yang dipersepsikan (perceived quality).

\section{Kualitas Layanan}

Pada saat ini persaingan dunia bisnis sangat ketat, sehingga layanan yang berkualitas menjadi suatu keharusan yang harus dimiliki oleh suatu perusahaan agar mampu mempertahankan konsumennya dan menjaga penjualan yang berkelanjutan. Kualitas layanan yaitu tingkat keunggulan sebuah layanan untuk memenuhi keinginan pelanggan (Tjiptono, 2006). Terdapat lima dimensi kualitas layanan, yaitu: bukti fisik (tangible), keandalan (reliability), ketanggapan (responsiveness), jaminan (assurance), dan empati (empathy) (Parasuraman et al, 1988). Kepuasan konsumen akan terpenuhi apabila proses penyampaian produk atau jasa dari suatu perusahaan kepada konsumen sesuai dengan apa yang dipersepsikan konsumen. Menurut Malik et al (2012) kualitas layanan merupakan faktor penting kepuasan pelanggan tidak hanya dalam industri manufaktur tetapi juga di perusahaan jasa. Hal ini dipertegas dari hasil penelitian Senthilkumar (2012) yang menunjukkan bahwa layanan pelanggan telah berpengaruh pada kepuasan pelanggan. Hal ini menunjukkan layanan berkualitas tinggi akan memiliki dampak positif pada kepuasan konsumen. kualitas layanan dipandang baik apabila memenuhi apa yang konsumen harapkan, sebaliknya kualitas layanan akan dipersepsikan buruk apabila tidak memenuhi harapan konsumen. Oleh karena itu untuk memenuhi kepuasan konsumen suatu perusahaan harus memperhatikan kualitas layanan yang ditawarkan kepada konsumenya.

\section{Harga}

Harga adalah sejumlah uang yang dibayarkan atas barang dan jasa, atau jumlah nilai yang konsumen tukarkan dalam rangka mendapatkan sejumlah kombinasi manfaat dari memiliki atau menggunakan barang atau jasa (Swastha, 1999). Harga juga menjadi titik utama bagi pelanggan untuk menilai apa yang ditawarkan di pasar (Monroe \& Lee, 1999). Menurut Kotler \& Amstrong (2008), ada empat indikator yang mencirikan harga yaitu: keterjangkauan harga, kesesuaian harga dengan kualitas produk, daya saing harga, serta kesesuaian harga dengan manfaat. Dalam membuat harga yang wajar dan terjangkau untuk produk informasi mendalam dari apa yang dipersepsikan oleh konsumen sangat diperlukan (Mannukka, 2005). Harga dapat digunakan sebagai sumber daya untuk meningkatkan keuntungan dan kepuasan pelanggan (Bhattacharya \& Friedman, 2001). Huber et al (2001) menunjukkan bahwa harga merupakan faktor penting bagi pelanggan ketika memilih produk atau jasa. Pernyataan tersebut didukung oleh penelitian 
Malik et al (2012) yang menunjukkan bahwa harga memiliki hubungan dengan kepuasan pelanggan. Ketika pelanggan percaya bahwa harga produk adalah wajar, perilaku pembelian cenderung diulang. Sebaliknya, jika pelanggan merasa bahwa produk atau layanan tertentu tidak layak harga, mereka tidak akan mengulangi perilaku pembelian (Ehsani \& Ehsani, 2014). Persepsi harga merupakan salah satu unsur psikologis yang memainkan peran penting dalam reaksi pelanggan untuk harga (Etzioni, 1988). Persepsi yang postif merupakan hasil dari rasa puas akan suatu pembelian yang dilakukannya, sedangkan persepsi yang negatif merupakan suatu bentuk dari ketidakpuasan konsumen atas produk atau jasa yang dibelinya. Dengan demikian diketahui bahwa pada tingkat harga tertentu, jika manfaat yang dirasakan meningkat, maka nilainya akan meningkat pula. Apabila nilai yang dirasakan pelanggan semakin tinggi, maka akan menciptakan kepuasan pelanggan yang maksimal (Tjiptono, 2006).

\section{METODE PENELITIAN}

\section{Desain Penelitian}

Penelitian ini merupakan penelitian yang bersifat descriptive research. Descriptive research bertujuan untuk menjelaskan hubungan atau pengaruh yang terdapat di antara variabel-variabel yang diteliti (Malhotra, 2010). Pengolahan data dilakukan dengan metode statisik menggunakan SPSS for windows.

\section{Defenisi Operasional}

- Kualitas produk $\left(\mathrm{X}_{1}\right)$ yaitu kemampuan suatu produk yang ditawarkan untuk menjalankan fungsi-fungsinya yang dapat memuaskan konsumen. Konstruk ini diukur melalui indikator dimensi kualitas produk meliputi kinerja (performance), keistimewaan (feature), keandalan (reliability), desain, daya tahan (durability), estetika serta perceived quality.

- Kualitas layanan adalah tingkat keunggulan layanan yang dapat memenuhi kepuasan konsumen. Konstruk ini diukur melalui lima indikator dimensi kualitas layanan meliputi tangibles, reliability, responsiveness, assurance, dan emphty.

- Harga merupakan sejumlah uang yang dibayarkan atas barang dan jasa atau jumlah nilai yang konsumen tukarkan dalam rangka mendapatkan sejumlah kombinasi manfaat dari memiliki atau menggunakan produk. Konstruk ini diukur melalui pertanyaan atau persepsi konsumen terhadap harga produk yang ditawarkan.

- Kepuasan konsumen adalah tingkat perasaan seseorang setelah membandingkan hasil yang dirasakan dengan harapannya atas produk atau layanan yang ditawarkan kepada konsumen. Konstruk ini diukur 
melalui pertanyaan yang mengarahkan pada sikap dan perasaan konsumen dalam menggunaka produk yang ditawarkan.

\section{Metode Pengambilan Sampel}

Populasi dalam penelitian ini adalah seluruh konsumen industry/ toko bakery di Kota Bengkulu. Sejauh ini belum ada data akurat yang dapat menyebutkan jumlah konsumen industry/ toko bakery di Kota Bengkulu. Oleh karena itu, besarnya populasi dalam penelitian ini tidak diketahui, sehingga teknik pengambilan sampel yang digunakan masuk dalam kategori non probability sampling, maka teknik pengambilan sampel non probabilitas yang dipilih adalah teknik judgemental (purposive). Teknik ini dipilih untuk memastikan bahwa hanya sampel yang memiliki unsur tertentu yang telah ditetapkan oleh peneliti yang akan diambil sebagai sampel (Black \& Champion, 2001: 264). Penyebaran kuesioner dilakukan secara langsung dengan cara menemui responden (konsumen) yang melakukan kunjungan atau pembelian produk pada toko bakery di Kota Bengkulu.

\section{Metode Pengumpulan Data}

Metode pengumpulan data yang digunakan berupa data sekuder dan primer. Data sekunder diperoleh melalui buku, artikel-artikel, situs-situs online mengenai bakery dan jurnal. Sedangkan data primer didapat melalui penyebaran kuisioner secara langsung dengan cara menemui responden (konsumen) yang melakukan kunjungan atau pembelian produk pada toko bakery di Kota Bengkulu. Agar mempermudah responden dalam memberikan jawaban, setiap jawaban atas pertanyaan dikuesioner yang diajukan pada responden diberi skor. Format kuesioner dirancang dengan menggunakan skala likert 1 sampai dengan 5. Skor 1 menunjukkan Sangat Tidak Setuju (STS); 2 Tidak Setuju (TS); 3 Cukup Setuju (CS); 4 Setuju (S); dan 5 Sangat Setuju (SS).

\section{Metode Analisis}

Data yang terkumpul melalui penyebaran kusioner, peneliti melakukan tabulasi frekuensi, untuk mengukur perilaku responden dalam melakukan pembelian pada industry/ toko bakery. Data ini dibuat untuk memperoleh informasi dan gambaran mengenai persepsi responden terhadap variabel yang digunakan dalam penelitian ini. Kemudian data yang terkumpul dari kuesioner diolah dengan menggunakan SPSS for windows.

\section{- Uji Validitas}

Uji validitas merujuk kepada sejauh mana suatu uji dapat mengukur apa yang sebenarnya ingin di ukur, keabsahan berkaitan dengan ketepatan dari prosedur pengukuran. Kriteria uji validitas menggunakan derajat kebebasan $(n-2)$ dan $\alpha=0.05$, maka apabila $r$ - hitung > $\mathrm{r}$ - tabel, berarti item tersebut valid. Uji validitas yang digunakan dalam penelitian ini adalah uji korelasi product moment. 
Nilai $r$ tabel yang digunakan berdasarkan tingkat keyakinan pada $\alpha=$ 0.05 sebesar 0.127 . Hasil koefisien korelasi yang dihasilkan dari setiap indikator yang digunakan dalam penelitian ini semuanya lebih besar $r$ tabel 0.127. Dengan demikian disimpulkan bahwa seluruh instrument penelitian adalah valid.

- Uji Reliabilitas

Uji reliabilitas yang digunakan dalam penelitian ini adalah teknik pengukuran Cronbach's Alpha, dimana nilainya harus lebih dari 0.6 ( $>0.6$ ) yang menunjukkan data konsisten dan layak untuk diproses lebih lanjut (Hair et al., 2010), Hasil pengujian reliabilitas instrument penelitian dapat dilihat pada Tabel 1 berikut ini.

Tabel 1 Hasil Uji Reliabilitas Variabel Penelitian

\begin{tabular}{|c|l|c|c|}
\hline No & \multicolumn{1}{|c|}{ Variabel } & Nilai Cronbach's Alpha & Keterangan \\
\hline 1 & Kualitas Produk & 0.882 & Reliabel \\
\hline 2 & Kualitas Layanan & 0.903 & Reliabel \\
\hline 3 & Harga & 0.685 & Reliabel \\
\hline 3 & $\begin{array}{l}\text { Kepuasan } \\
\text { Konsumen }\end{array}$ & 0.716 & Reliabel \\
\hline
\end{tabular}

Sumber: Hasil Penelitian 2016, data di olah

Berdasarkan Tabel 1 tersebut diketahui bahawa koefisien cronbach's alpha variabel penelitian seluruhnya lebih besar dari nilai 0.60 , yang bearti bahwa seluruh variabel penelitian adalah reliabel (handal).

- Analisis Regresi Linier Berganda (Multiple Regression)

Kegunaan regresi linier berganda adalah untuk meramalkan nilai variabel terikat (Y) apabila variabel bebasnya $(\mathrm{X})$ dua atau lebih. Sesuai dengan model penelitian, regresi linier berganda dalam penelitian ini dilakukan untuk menguji pengaruh antara variabel bebas kualitas produk, kualitas layanan dan harga dengan variabel terikat kepuasan konsumen. Secara matematis, persamaannya adalah sebagai berikut:

$$
Y=a+\beta_{1} X_{1}+\beta_{2} X_{2}+\beta_{3} X_{3}
$$

Proses perhitungan statistika dilakukan menggunakan SPSS 16. Setelah itu akan diperoleh hasil output berupa model summary, ANOVA tabel, dan coefficient table. Secara statistik setidaknya ini dapat diukur dari nilai koefisien determinasi $\left(\mathrm{R}^{2}\right)$, nilai statistik $\mathrm{F}$ dan nilai statistik t. Perhitungan statistik disebut signifikan secara statistik apabila nilai uji statistiknya berada dalam daerah kritis (daerah dimana Ho ditolak), sebaliknya disebut tidak signifikan bila nilai uji statistiknya berada dalam daerah dimana Ho diterima (Ghozali, 2006). Rumusan hipotesis $\mathrm{H}_{\mathrm{o}}$ dan $\mathrm{H}_{1}$ :

$\mathrm{H}_{\mathrm{o}}: \mathrm{R}=$ Tidak ada pengaruh variabel bebas terhadap variabel terikat. $\mathrm{H}_{1} \neq \mathrm{R}=$ Ada pengaruh variabel bebas terhadap variabel terikat. 


\section{HASIL PENELITIAN DAN PEMBAHASAN}

\section{Persepsi Responden Terhadap Variabel Penelitian}

Nilai rata-rata jawaban responden terhadap variabel kualitas produk sebesar 4.09 (puas), variabel kualitas layanan sebesar 3.87 (puas), variabel harga sebesar 3.75 (puas), dan variabel kepuasan konsumen sebesar 4.00 (puas). Hal ini menunjukkan bahwa responden merasa puas dengan kualitas produk, kualitas layanan dan harga yang ditawarkan oleh industry/ toko bakery di Kota Bengkulu. Dengan demikian pihak industry/ toko bakery di Kota Bengkulu harus mempertahankan dan dapat meningkatkan lagi kualitas produk, kualitas layanan dan harga yang ditetapkan tersebut.

Jika dilihat dari hasil rata-rata indikator pada variabel penelitian yang mendapatkan nilai rata-rata terendah secara keseluruah, maka ada beberapa hal yang perlu dilakukakan oleh pihak industry/ toko bakery di Kota Bengkulu dalam mempertahankan dan meningkatkan kepuasan konsumennya, yaitu 1). Memperbaiki/ membuat kemasan produk yang lebih menarik lagi misalnya: menambah penak-pernik atau memvariasikan produk yang lebih menarik lagi dan tentunya sesuai dengan keinginan konsumen; 2). Karyawan industry/ toko bakery di Kota Bengkulu harus lebih bersikap ramah dan sopan lagi dalam melayani konsumen misalnya selalu memberikan senyuman dan selalu bertutur kata dengan baik dan benar sehingga konsumen lebih puas lagi terhadap pelayanan yang diberikan; 3). Dalam menetapkan harga harus selalu memperhatikan harga produk dipasaran saat ini sehingga harga yang ditawarkan bersaing; serta 4). Pihak industry/ toko bakery di Kota Bengkulu harus menerima semua keluhan dan saran-saran dari konsumen yang berguna untuk peningkatan kualitas yang diberikan kepada konsumen seperti terus meyakinkan kepada konsumen bahwa produk bakery yang ditawarkan merupakan produk-produk yang berkualitas.

\section{Hasil Analisis Regresi Linier Berganda (Multiple Regression)}

Analisis regresi linier berganda (multiple regression linear) dilakukan untuk membuktikan ada tidaknya pengaruh variabel kualitas produk, kualitas layanan dan harga terhadap kepuasan konsumen. Guna memudakan perhitungannya, digunakan bantuan program SPSS for windows. Berikut ini disajikan hasil analisis regresi linier berganda (multiple regression linear). 
Tabel 2 Uji F (ANOVA ${ }^{b}$ )

\begin{tabular}{|c|c|c|c|c|c|c|}
\hline \multicolumn{2}{|c|}{ Model } & Sum of Squares & df & Mean Square & $\mathrm{F}$ & Sig. \\
\hline 1 & Regression & 594.712 & 3 & 198.237 & 46.404 & $.000^{a}$ \\
\hline & Residual & 1008.184 & 236 & 4.272 & & \\
\hline & Total & 1602.896 & 239 & & & \\
\hline
\end{tabular}

a. Predictors: (Constant), Price, Service Quality, Product Quality

b. Dependent Variable: Customer Satisfaction

Sumber: Hasil Penelitian 2016

Berdasarkan Tabel 2, diketahui bahwa nilai probabilitas (sig) $0.000<$ alpha 0.05 , yang berarti bahwa variabel kualitas produk, kualitas layanan dan harga secara simultan berpengaruh signifikan terhadap kepuasan konsumen. Selanjutnya untuk melihat pengaruh variabel kualitas produk, kualitas layanan dan harga terhadap kepuasan konsumen secara parsial dapat dilihat pada Tabel 3 berikut ini.

Tabel 3 Uji t (Coefficients ${ }^{a}$ )

\begin{tabular}{|c|c|c|c|c|c|}
\hline \multirow[b]{2}{*}{ Model } & \multicolumn{2}{|c|}{$\begin{array}{l}\text { Unstandardized } \\
\text { Coefficients }\end{array}$} & \multirow{2}{*}{$\begin{array}{c}\text { Standardized } \\
\text { Coefficients } \\
\text { Beta }\end{array}$} & \multirow[b]{2}{*}{$\mathrm{t}$} & \multirow[b]{2}{*}{ Sig. } \\
\hline & B & Std. Error & & & \\
\hline 1 (Constant) & 11.192 & 1.484 & & 7.543 & .000 \\
\hline Product Quality & .294 & .058 & .332 & 5.045 & .000 \\
\hline Service Quality & .224 & .040 & .357 & 5.557 & .000 \\
\hline Price & -.170 & .060 & -.150 & -2.828 & .005 \\
\hline
\end{tabular}

a. Dependent Variable: Customer Satisfaction

Sumber: Hasil Penelitian 2016

Pada Tabel 3, diketahui bahwa variabel kualitas produk, kualitas layanan dan harga secara parsial berpengaruh signifikan terhadap kepuasan konsumen. Hal ini karenakan nilai probabilitas (sig) setiap variabel < alpha 0.05 . Berdasarkan Tabel 4, juga dapat diperoleh persamaan regresi sebagai berikut:

$$
Y=11.192+0.294 X_{1}+0.224 X_{2}-0.170 X_{3}
$$

Dari persamaan regresi tersebut diketahui bahwa nilai koefisien regresi untuk variabel kualitas produk dan kualitas layanan positif. Hal ini menunjukkan bahwa variabel kualitas produk $\left(\mathrm{X}_{1}\right)$ dan kualitas layanan $\left(\mathrm{X}_{2}\right)$ berpengaruh positif terhadap kepuasan konsumen (Y) dengan nilai koefisien regresi masing-masing sebesar 0.294 dan 0.224 . Sedangkan variabel harga diketahui nilai koefisien regresi negatif yaitu -0.170 . Hal ini menunjukkan bahwa variabel harga $\left(\mathrm{X}_{3}\right)$ berpengaruh negatif terhadap kepuasan konsumen (Y). Kemudian untuk melihat keeratan hubungan dan seberapa 
besar pengaruh variabel kualitas produk, pelayanan dan harga terhadap kepuasan konsumen dapat dilihat pada tabel 4 berikut ini:

Tabel 4 Model Summary ${ }^{b}$

\begin{tabular}{|l|r|r|r|r|r|}
\hline Model & \multicolumn{1}{|c|}{$\mathrm{R}$} & $\mathrm{R}$ Square & $\begin{array}{c}\text { Adjusted R } \\
\text { Square }\end{array}$ & $\begin{array}{c}\text { Std. Error of the } \\
\text { Estimate }\end{array}$ & Durbin-Watson \\
\hline 1 & $.609^{\mathrm{a}}$ & .371 & .363 & 2.067 & 2.083 \\
\hline
\end{tabular}

a. Predictors: (Constant), Price, Service Quality, Product Quality

b. Dependent Variable: Customer Satisfaction

Sumber: Hasil Penelitian 2016

Berdasarkan Tabel 5, diketahui nilai koefisien korelasi berganda $(\mathrm{R})=$ 0.609, hal ini menunjukkan bahwa variabel kualitas produk, kualitas layanan dan harga memiliki keeratan hubungan dengan variabel kepuasan konsumen sebesar $60.9 \%$. Sedangkan nilai koefisien determinasi berganda $\left(\mathrm{R}^{2}\right)=0.371$. Ini berarti bahwa variabel kualitas produk, kualitas layanan dan harga yang digunakan dalam persamaan regresi ini secara bersamasama berpengaruh sebesar $37.1 \%$ terhadap kepuasan konsumen, sedangkan sisanya dipengaruhi oleh variabel lain di luar penelitian.

\section{PEMBAHASAN}

\section{Pengaruh Kualitas Produk Terhadap Kepuasan Konsumen}

Hanya ada dua pilihan bagi perusahaan yaitu sukses dalam pengembangan produk sehingga menghasilkan produk yang unggul atau gagal dalam pencapaian tujuan bisnisnya karena produk yang tidak mampu bersaing dipasar (Cooper \& Kleinschmidt, 1987). Suatu produk dapat memuaskan konsumen bila dinilai dapat memenuhi atau melebihi keinginan dan harapannya (Spreng et al., 1996). Ini menunjukkan bahwa kualitas produk merupakan faktor yang sangat diperhatikan oleh pelanggan dalam membentuk kepuasan konsumen. Berdasarkan hasil penelitian diketahui bahwa kualitas produk berpengaruh positif dan signifikan terhadap kepuasan konsumen dengan koefisien regresi sebesar 0.294 dan nilai probabilitas (sig.) $0.000<$ alpha 0.05 . Hal ini menunjukkan bahwa jika semakin baik kualitas produk industry/ toko Bakery di Kota Bengkulu maka kepuasan konsumen juga akan semakin tinggi. Hasil penelitian ini didukung oleh penelitian Senthilkumar (2012) yang menyatakan bahwa kualitas produk berpengaruh pada kepuasan pelanggan. Assauri (2004) mengatakan bahwa kualitas produk merupakan faktor-faktor yang terdapat dalam suatu barang atau hasil yang menyebabkan barang atau hasil tersebut sesuai dengan tujuan untuk apa barang atau hasil itu dimaksudkan. Tjiptono (2006) menyatakan ada beberapa faktor yang digunakan untuk mengevaluasi 
tercapainya pemenuhan kebutuhan oleh suatu produk yaitu: kinerja (performance), ciri-ciri atau keistimewaan tambahan (feature), keandalan (reliability), kesesuaian dengan spesifikasi (conformance to specification), daya tahan (durability), servicebility, estetika serta kualitas yang dipersepsikan (perceived quality).

2. Pengaruh Kualitas Layanan Terhadap Kepuasan Konsumen

Pada saat ini persaingan dunia bisnis sangat ketat, sehingga layanan yang berkualitas menjadi suatu keharusan yang harus dimiliki oleh suatu perusahaan agar mampu mempertahankan konsumennya dan menjaga penjualan yang berkelanjutan. Menurut Malik et al (2012) kualitas layanan merupakan faktor penting kepuasan pelanggan tidak hanya dalam industri manufaktur tetapi juga di perusahaan jasa. Berdasarkan hasil penelitian diketahui bahwa kualitas layanan berpengaruh positif dan signifikan terhadap kepuasan konsumen dengan koefisien regresi sebesar 0.224 dan nilai probabilitas (sig.) $0.000<$ alpha 0.05 . Hal ini menunjukkan bahwa jika semakin baik kualitas layanan industry/ toko Bakery di Kota Bengkulu maka kepuasan konsumen juga semakin tinggi. Hal ini dipertegas dari hasil penelitian Senthilkumar (2012) yang menunjukkan bahwa layanan pelanggan telah berpengaruh pada kepuasan pelanggan. Hal ini menunjukkan layanan berkualitas tinggi akan memiliki dampak positif pada kepuasan konsumen. Kualitas layanan dipandang baik apabila memenuhi apa yang konsumen harapkan, sebaliknya kualitas layanan akan dipersepsikan buruk apabila tidak memenuhi harapan konsumen. Oleh karena itu untuk memenuhi kepuasan konsumen suatu perusahaan harus memperhatikan kualitas layanan yang ditawarkan kepada konsumenya. Kualitas layanan yaitu tingkat keunggulan sebuah layanan untuk memenuhi keinginan pelanggan (Tjiptono, 2006). Terdapat lima dimensi kualitas layanan, yaitu: bukti fisik (tangible), keandalan (reliability), ketanggapan (responsiveness), jaminan (assurance), dan empati (empathy) (Parasuraman et al, 1988). Kepuasan konsumen akan terpenuhi apabila proses penyampaian produk atau jasa dari suatu perusahaan kepada konsumen sesuai dengan apa yang dipersepsikan konsumen.

\section{Pengaruh Harga Terhadap Kepuasan Konsumen}

Harga adalah sejumlah uang yang dibayarkan atas barang dan jasa, atau jumlah nilai yang konsumen tukarkan dalam rangka mendapatkan sejumlah kombinasi manfaat dari memiliki atau menggunakan barang atau jasa (Swastha, 1999). Harga dapat digunakan sebagai sumber daya untuk meningkatkan keuntungan dan kepuasan pelanggan (Bhattacharya \& Friedman, 2001). Huber et al (2001) menunjukkan bahwa harga merupakan faktor penting bagi pelanggan ketika memilih produk atau jasa. Berdasarkan hasil penelitian diketahui bahwa harga berpengaruh negatif dan signifikan terhadap kepuasan konsumen dengan koefisien regresi - 0.170 dan nilai 
probabilitas (sig.) 0.005 < alpha 0.05. Hal ini menunjukkan bahwa jika semakin rendah harga produk yang ditawarkan industry/ toko Bakery di Kota Bengkulu maka kepuasan konsumen akan semakin tinggi. Pernyataan tersebut didukung oleh penelitian Malik et al (2012) yang menunjukkan bahwa harga memiliki hubungan dengan kepuasan pelanggan, kenaikan harga telah terbukti memiliki dampak negatif pada kepuasan pelanggan. Ketika pelanggan percaya bahwa harga produk adalah wajar, perilaku pembelian cenderung diulang. Sebaliknya, jika pelanggan merasa bahwa produk atau layanan tertentu tidak layak harga, mereka tidak akan mengulangi perilaku pembelian (Ehsani \& Ehsani, 2014). Menurut Kotler \& Amstrong (2008), ada empat indikator yang mencirikan harga yaitu: keterjangkauan harga, kesesuaian harga dengan kualitas produk, daya saing harga, serta kesesuaian harga dengan manfaat. Dalam membuat harga yang wajar dan terjangkau untuk produk informasi mendalam dari apa yang dipersepsikan oleh konsumen sangat diperlukan (Mannukka, 2005). Persepsi harga merupakan salah satu unsur psikologis yang memainkan peran penting dalam reaksi pelanggan untuk harga (Etzioni, 1988). Apabila nilai yang dirasakan pelanggan semakin tinggi, maka akan menciptakan kepuasan pelanggan yang maksimal (Tjiptono, 2006).

\section{KESIMPULAN}

Berdasarkan hasil penelitian dan pembahasan, dapat diambil kesimpulan yakni sebagai berikut:

1. Kualitas produk berpengaruh positif dan signifikan terhadap kepuasan konsumen, yang berarti bahwa semakin baik kualitas produk industry/ toko Bakery di Kota Bengkulu maka kepuasan konsumen juga akan semakin tinggi.

2. Kualitas layanan berpengaruh positif dan signifikan terhadap kepuasan konsumen, yang berarti bahwa jika semakin baik kualitas layanan industry/ toko Bakery di Kota Bengkulu maka kepuasan konsumen semakin tinggi.

3. Harga berpengaruh negatif dan signifikan terhadap kepuasan konsumen dengan. Hal ini menunjukkan bahwa jika semakin rendah harga produk yang ditawarkan industry/ toko Bakery di Kota Bengkulu maka kepuasan konsumen akan semakin tinggi

4. Kualitas produk, kualitas layanan dan harga secara simultan (bersama-sama) berpengaruh signifikan terhadap kepuasan konsumen. Artinya bahwa semakin puas konsumen terhadap kualitas produk, kualitas layanan dan harga maka semakin tinggi kepuasan konsumen terhadap industry/ toko Bakery di Kota Bengkulu. 


\section{SARAN}

Berdasarkan hasil penelitian dan pembahasan, maka peneliti memberikan beberapa saran yang dapat dipertimbangkan berkaitan dengan hasil penelitian yakni kualitas produk, kualitas layanan dan harga merupakan faktor penentu kepuasan konsumen. Ada beberapa hal yang diharapkan untuk dapat dilakukan pihak industry/ toko bakery di Kota Bengkulu dalam mempertahankan dan meningkatkan kepuasan konsumennya yaitu:

1. Pihak industry/ toko bakery di Kota Bengkulu diharapkan memperbaiki/ membuat kemasan produk yang lebih menarik lagi misalnya: menambah penak-pernik atau memvariasikan produk yang lebih menarik dan tentunya sesuai dengan keinginan konsumen sehingga kepuasan konsumen lebih maksimal terhadap produk yang ditawarkan.

2. Karyawan industry/ toko bakery di Kota Bengkulu harus lebih bersikap ramah dan sopan lagi dalam melayani konsumen misalnya selalu memberikan senyuman dan selalu bertutur kata dengan baik dan benar sehingga konsumen lebih puas lagi terhadap pelayanan yang diberikan;

3. Pihak industry/ toko bakery di Kota Bengkulu dalam menetapkan harga harus selalu memperhatikan harga produk dipasaran saat ini sehingga harga yang ditawarkan bersaing dan tentunya harga produk yang ditawarkan harus sesuai dengan kualitas produk yang diberikan kepada konsumen sehingga konsumen lebih puas lagi dengan harga yang ditawarkan.

4. Pihak industry/ toko bakery di Kota Bengkulu harus menerima semua keluhan dan saran-saran dari konsumen yang berguna untuk peningkatan kualitas yang diberikan kepada konsumen seperti terus meyakinkan kepada konsumen bahwa produk bakery yang ditawarkan merupakan produkproduk yang berkualitas.

\section{DAFTAR PUSTAKA}

Assauri, S. (2004). "Manajemen Pemasaran". PT. Rajagrafindo Persada, Jakarta. Bhattacharya, A., \& Friedman, H. H. (2001). "Using "smart" pricing to increase profits and maximize customer satisfaction". The National Public Accountant, 46 (6), 34-37.

Black, J. A., \& Champion, D. J. (2001). "Metode dan Masalah Penelitian Sosial (Terjemahan"). Bandung, Refika Aditama.

Cooper R. G., \& Kleinschmidt, E. J. (1987). "What Makes a New Product a Winner: Success Factors at The Project Level", $R \&$ D Management, 175189.

Crosby, L. A., Evans, K. R., \& Cowles, D. (1990). "Relationship Quality in Services Selling: An Interpersonal Influence Perspective". The Journal of Marketing, 54(3), 68-81. 
Dapkevicius, A., \& Melnikas, B. (2009). "Influence of Price and Quality to Customer Satisfaction: Neuromarketing Approach". Science Future of Lithuania, 3 (1).

Ehsani, Z., \& Ehsani, H. M. (2014). "Effect of Quality and Price on Customer Satisfaction and Commitment in Iran Auto Industry". International Journal of Service Science, Management and Engineering. 5 (1), 52-56.

Etzioni, A. (1988). "The Moral Dimension: Toward a New Economics". NewYork: Free Press.

Fatona, S. (2010). "Kualitas Jasa yang Mempengaruhi Loyalitas dan Relevansinya terhadap Kepuasan". Jurnal Dinamika Manajemen. Vol. 1, No.1, pp: 41-46.

Ghozali, I. (2006). "Aplikasi Analisis Multivariate dengan Program SPSS". Badan Penerbit Universitas Diponegoro: Semarang.

Hair, F. F., Black, W. C., Babin, B. J., \& Anderson, R. E. (2010). "Multivariate Data Analysis". 7th. NJ: Pearson Prentice Hall.

Hermann, A., Xia, L., Monroe, K. B., \& Huber, F. (2007). "The influence of price fairness on customer satisfaction: an empirical test in the context of automobile purchases". Journal of Product \& Brand Management , 49 58.

Huber, F., Herrmann, A., \& Wricke, M. (2001). "Customer satisfaction as an antecedent of price acceptance: results of an empirical study". Journal of Product \& Brand Management, 10 (3), 160-169.

Kotler, P., \& Amstrong, G. (2008). "Principles of Marketing". International Edition, Jilid 12. N.J: Prentice- Hall International, Inc.

Malhotra, N. K. (2010). "Marketing research: An applied orientation". (6th ed.), New Jersey: Pearson.

Malik, E. M., Ghafoor, M. M., \& Iqbal, K. H. (2012). "Impact of Brand Image, Service Quality and Price on Customer Satisfaction in Pakistan Telecommunication Sector". International Journal of Business and Social Science, 23 (3).

Mannukka, J. (2005). "Dynamics of Price Sensitivity Among Mobile Service Customers". Journal of Product \& Brand Management, 1 (14), 65-73.

Monroe, K. B., \& Lee, A. Y. (1999). "Remembering Versus Knowing: Issues in Buyers Processing of Price Information". Journal of the Academy of Marketing Science, (27), 207-25.

Parasuraman, A., Zeithaml, Valerie, and Berry, L. (1988). "Servqual: Multiple Item Scale for Measuring Consumer Perceptions of Service Quality", Journal of Retailing, Vol. 64, p.12 - 36.

Senthilkumar, V. (2012). "A Study on The Effects of Customer Service and Product Quality on Customer Satisfaction and Loyalty". Namex International Journal of Management Research. Issue 2 (2).

Spraeng, Richard A., Mackenzie, Scott B., \& Richard W. Olshavsky. (1996). “A Reexamination of the Determinants of Consumer Satisfaction", Journal of Marketing, Vol. 60 (July 1996), 15-32.

Stephen, L. S Jr., Omar, W. M., Wahid, A. N., Ismail, I., dan Harun, A. (2007). "The Effect of Brand Image on Overall Satisfaction and Loyalty Intention 
In The Context of Color Cosmetic". Asian Academy of Management Journal, 12, 83-107.

Swastha, B. (1999). "Asas-Asas Pemasaran". Edisi Ketiga. Penerbit Liberty: Yogyakarta.

Tjiptono, F. (2006). "Strategi Pemasaran". Penerbit Andi, Yogyakarta.

www.jsm-synergy.com. "Prospek Industri dan Pemasaran Bakery di Indonesia 2011 - 2015". http://www.jsm-synergy.com/our-publication/ journalresearch/124-prospek - industri-dan-pemasaran -bakery- di-indonesia2011-2015. Akses, Juli 2016.

Yi, Y. (1990). "A Critical Review of Consumer Satisfaction, in Review of Marketing". Chicago: American Marketing Association, 68-123. 